\title{
A hyperaemiás és a nonhyperaemiás intrakoronáriás nyomásarányok együttes értékelésének diagnosztikus jelentősége
}

\author{
Üveges Áron, 2,3, Tar Balázs',3, Jenei Csabaa ${ }^{2,3}$, Szabó Gábor Tamáss, \\ Köszegi Zsolt', 2,3
}

\author{
'Szabolcs-Szatmár-Bereg Megyei Kórházak és Egyetemi Oktatókórház, Jósa András Oktatókórház, \\ III. sz. Belgyógyászati Osztály, Nyíregyháza \\ ${ }^{2}$ Debreceni Egyetem, Kardiológiai és Szívsebészeti Klinika, Debrecen \\ ${ }^{3}$ Debreceni Egyetem, Laki Kálmán Doktori Iskola, Debrecen
}

Levelezési cím:

Dr. Kőszegi Zsolt, e-mail: koszegi@med.unideb.hu

Nemrégiben két nagy esetszámú tanulmány igazolta, hogy vazodilatációs provokáció nélkül a koszorúér-szükület után/ elött mért nyomáshányados alapján vezérelt revaszkularizáció hasonló klinikai kimenetelt eredményez, mint a maximális vazodilatációban meghatározható frakcionális áramlási rezerv (FFR) által vezérelt revaszkularizáció. Azonban jelenleg még nem pontosan tisztázott, hogy mi a klinikai jelentősége a hyperaemia nélküli és a hyperaemia melletti nyomáshányadosok különböző eredményeinek. Összefoglalónkban bemutatjuk a koszorúérben különböző körülmények között kialakuló nyomásgrádiensek patofiziológiai hátterét és az ebből levonható klinikai következtetéseket. Részletezzük a kombinált mérésekkel elérhető információk értékét az epikardiális és a mikrovaszkuláris elváltozások vonatkozásában. Felvázoljuk a klinikai döntéshozás egyik lehetséges algoritmusát, amely a szükületek funkcionális értékelését a kevésbé invazív képalapú (image based) FFR-számítással kezdi. Amit bizonyos értéktartomány $(0,75-0,85)$ esetén nyugalmi és vazodilatációs invazív nyomáshányados együttes mérését is ajánljuk.

A komplex stratégia alapján a ma még döntően a szükületek anatómiai megjelenésén alapuló döntéshozás helyett teljes körű képet kaphatunk a koszorúér-betegség patofiziológia jellemzőiröl, és meghozhatjuk a legmegfelelöbb döntést a revaszkularizáció szükségességét és a gyógyszeres kezelés irányát illetően.

Kulcsszavak: FFR, iFR, nyugalmi $P_{\mathrm{d}} / P_{a}$, patofiziológia

Diagnostic value of combined evaluation of hyperemic and non-hyperemic intracoronary pressure ratios Recently, two large scale outcome trial have proved that non-hyperemic pressure ratio has similar ability for the guidance of revascularization of coronary stenosis than using the hyperemic fractional flow reserve (FFR). However, the relevance of the discordant results between the hyperemic and non-hyperemic pressure ratios has not clarified. In this review we describe the clinical value and the physiological mechanism of the pressure gradients during different flow condition in the coronary artery. We explore the possibilities of the combined measurements for detecting myocardial ischemia caused by either epicardial or microvascular components. We also propose an algorithm for the evaluation of the functional relevance of the coronary stenosis starting by the less invasive image based FFR calculations followed by invasive non-hyperemic and hyperemic pressure ratio measurements in case of the interval between $0.75-0.85$ of the image based FFR values.

In our opinion this complex strategy provides comprehensive evaluation of the pathophysiological state of the coronary disease beyond the morphological features of the stenoses and allows us to choose the most appropriate therapy for the patient.

Keywords: FFR, iFR, non-hyperemic $\mathrm{P}_{\mathrm{d}} / \mathrm{P}_{\mathrm{a}}$, pathophysiology 


\section{Bevezetés}

A perkután koszorúér-intervenció klinikai bevezetésével egyidejüleg már 1977-ben felmerült az igény a koszorúér-szűkület jelentőségének intrakoronáriás nyomásméréssel történő meghatározására. Maga Andreas Grüntzig is felismerte, hogy a koronária-intervenció indikálásához és annak eredményének a felméréséhez hasznos lehet az intrakoronáriás nyomásmérés. Az akkori technikai lehetőségek a koszorúéren belül a szükülettől disztálisan nyomás mérését csak a ballonkatéter lumenén keresztül tették lehetővé (1). Grüntzig már azzal is szembesült, hogy a nyugalmi nyomás mérése gyakran nem hordoz elég információt a szűkület jelentőségének a megítélésére (2). Ha tehette volna, feltehetően mind a nyugalmi, mind a hyperaemias értékeket figyelembe vette volna a döntéshozatala során.

Az 1990-es években Nico Pijls és Bernard De Bruyne kidolgozták a frakcional flow reserve (FFR) koncepcióját, amely a szükület hatására hyperaemia alatt kialakuló nyomásesés mérésén alapul $(3,4)$. A méréshez szükséges technikai feltételek megvalósítását követően a módszer a kétezres években nagy sikerrel terjedt a világon, és a DEFER (5) és a FAME (6-9) vizsgálatokat követően 2010-ben az Európai Kardiológus Társaságnak (ESC) a miokardiális revaszkularizációra vonatkozó ajánlásába is bekerült az eljárás (10).

\section{A frakcionális áramlási rezerv koncepciója}

Az FFR koncepciója arra alapult, hogy a szúkületet követő nyomásesés arányos a szívizom számára bekövetkező perfúziós nyomás esésével, így ez az érték megmutatja, hogy maximális vazodilatáció (hyperaemia) alatt hányad részére csökken a véráramlás (ahhoz képest, mintha nem lenne szükület). Ennek alapján elvileg az is megjósolható, hogy milyen mértékủ áramlásfokozódás következik be a szükület megszüntetésekor. Ez a prekoncepció azonban csak közelítéssel igaz, mivel az áramlási törvényszerüségeket figyelembe véve bizonyos nyomásveszteség az áramlás során mindig kialakul. Tehát az ép koszorúéren feltételezett 1,00 FFR normálérték elhanyagolja a Poisseuille-törvény szerint mindig létrejövő áramlási nyomásveszteséget (11). Más kérdés, hogy amikor nyugalmi vagy hyperaemiás disztális nyomást mérünk, az nemcsak az áramlási nyomásveszteségből adódó nyomásesést mutatja, hanem hozzáadódik a hidrosztatikai nyomás is. Az utóbbival magyarázhatjuk, hogy bizonyos esetekben, a disztális nyomás a proximális nyomásnál magasabb is lehet (így a mért nyomásarány nagyobb, mint 1,00), ha a disztális szenzort több cm-rel a nyomásmérő szenzor szintje alá vezetjük az érben (pl. érdemi szükület nélküli körbefutó ágon) (12).

Az FFR-koncepciót korábban noninvazív iszkémiás paraméterekkel validálták. Kezdetben a terheléses EKG- val bizonyított egyértelmű iszkémiát a $F F R<0,66$ értékénél figyelték meg (13). Később különböző képalkotó eljárásokkal, beleértve a perfúziós PET-vizsgálatot is, azt találták, hogy a képalkotó eljárással kimutatható iszkémiára a 0,75 FFR-határérték alatti értékek jellemzőek $(3,4)$. A továbbiakban a klinikai vizsgálatok indításakor (pl. a DEFER-studyban), szintén ez a 0,75 érték szerepelt, amely alapján biztonsággal halaszthatónak bizonyult az adott lézió intervenciója, amennyiben ezen határ fölötti értéket mértek (5). Még később azonban ez az érték - amit ma is a revaszkularizáció indikációjának tekintünk - 0,80-ra emelkedett (6-9). A FAME 2-vizsgálat eredménye szerint, ha a 0,80 érték alatt nem történt meg a revaszkularizáció, úgy a kedvezőtlen végpontok egy év elteltével több, mint kétszer gyakrabban fordultak elő, mint a stenteléssel kezelt csoportban. A végpontokat a revaszkularizációs események dominálták.

Azonban a FAME 2-tanulmányban a küszöbérték feletti FFR-értékkel rendelkező betegek szintén jelentős kockázatot mutattak kedvezőtlen kardiovaszkuláris eseményekre vonatkozóan: a vizsgálat regiszterágára került ezen betegek 12\%-ánál történt az utánkövetési idő alatt revaszkularizáció. Másfelől a csökkent FFR-értéket $(<0,80)$ mutató, de gyógyszeres kezelésre randomizált betegek 52,6\%-ánál nem következett be esemény a kétéves utánkövetési idő alatt (59,4\%-nál semmilyen revaszkularizáció sem történt). Ez alapján a 0,80 FFR-határérték csak <50\%-os szenzitivitással jelezte előre a nemkívánatos esemény bekövetkeztét (9).

\section{A nonhyperaemiás nyomásparaméterek klinikai alkalmazása}

Ha megnézzük az újabban használt non-hyperaemias értékeket, ezek teljesítőképessége az adverz esemény előrejelzését illetően nagyon hasonlónak bizonyult az FFR-rel vezérelt stratégiához. Nagy esetszámú randomizált tanulmányok (DEFINE-FLAIR és az IFR SWEDEHEART) igazolták, hogy a diasztolé bizonyos szakaszában mért nyugalmi disztális/proximális nyomásarány az ún. instantenous wave-free ratio (iFR) az FFR-hez hasonló módon alkalmas a revaszkularizáció szükségességének a megítélésére $(14,15)$. A 0,89 iFR-határértéket használva nem volt szignifikáns különbség a 0,80 FFR-határérték alapján revaszkularizált betegek kimeneteléhez képest. Ezért az Európai Kardiológus Társaság 2019-es ajánlása szerint a krónikus koronária szindrómában a koronarográfián látott szükület jelentőségének megítélésére 50-90\% közötti átmérőcsökkenés esetén az iFR- és az FFR-mérés egyaránt IA-szintü javaslattal szerepel (15).

Az iFR-ről bebizonyosodott, hogy szorosan összefügg szívciklus átlagos nyugalmi disztális/proximális (az utóbbi az aortanyomásnak felel meg) nyomásarányával $\left(P_{d} / P_{a}\right) . A P_{d} / P_{a}$ a 0,80 FFR-értekkel a legjobb egy- 
beesést 0,92 határértéknél mutatta (17). Ennek alapján az iFR helyett a speciális szoftver nélkül is leolvasható nyugalmi $P_{d} / P_{a}$ is használható.

Bár a fent említett eljárások közül egyik sem tekinthető az iszkémia-kimutatás aranystandardjának (és azt is láttuk, hogy a küszöbértékek az idők során jelentősen változtak), mégis jelenlegi tudásunk szerint a fenti határértékek a legjobban használható paraméterek a klinikai döntéshozásban. A nyugalmi és a hyperaemiás eljárások közötti esetleges prognosztikai különbség jelenleg még nem teljesen feltárt, mivel a közlemények alapján ellentétes következtetések vonhatók le. Az iFR-nek az FFR-rel szembeni non-inferior eredményei mellett, az egyik tanulmányban az infarktus és a halálozás nem szignifikáns mértékben ugyan, de magasabb volt az iFR-rel vezérelt betegcsoportban (18). Ezzel szemben a DEFINE-FLAIR (Functional Lesion Assessment of Intermediate Stenosis to Guide Revascularisation) tanulmány post hoc analízise arra hívta fel a figyelmet, hogy az a LAD-szükületek esetében éppen az iFR-vezérelt stratégia bizonyult hatékonyabbnak a kedvezőtlen események kivédése szempontjából: az iFR-eredmény alapján nem revaszkularizált betegeknél (elsősorban a nem tervezett revaszkularizációk kevesebb előfordulása miatt) szignifikánsan kevesebb adverz esemény fordult elő, mint az FFR alapján nem stentelteknél (19). Ebben a tanulmányban a jelenség hátterét azzal magyarázták, hogy a nyugalmi nyomásgrádiens az, amelyik szorosabban összefügg az adott ér iszkémia-okozó tulajdonságával. Mivel a közvetlenebb áramlási információt nyújtó koronária flow rezerv (CFR) értéket jobb prognosztikai paraméternek tartják
$(19,20)$, így feltételezésük szerint a normál FFR ellenére kórosan alacsony CFR okozhatta a rosszabb kimenetelt az FFR-vezérelt ágon.

Ezen túlmenően van olyan vélemény is, amely szerint a hyperaemiában jelentkező jelentős nyomásesés nem feltétlenül jelent miokardiális iszkémiát (22-25), mivel az megtartott CFR mellett is kialakulhat.

A CFR/FFR ellentmondás vonatkozásban különösen nagy várakozással tekinthetünk a DEFINE-FLOW (Distal Evaluation of Functional Performance With Intravascular Sensors to Assess the Narrowing Effect - Combined Pressure and Doppler FLOW Velocity Measurements) study majdani eredményeire. A tanulmányban 455 beteg bevonásával intrakoronáriás nyomás- és Doppler-méréssel kombinálva randomizálva vizsgálják a CFR/FFR diszkordancia (CFR $\geq 2,0$ és $F F R \leq 0,8)$ esetén a gyógyszeres kezelés eredményeit a stenteléssel szemben.

\section{A nyugalmi nyomásarány patofiziológiai jelentése}

A nyugalomban is mérhető disztális nyomás csökkenése esetén a koronária-autoreguláció úgy tudja csak fenntartani a normál nyugalmi perfúziót, ha a rezisztenciaerek dilatációja révén csökkenti a miokardiális szintű áramlási ellenállást. Ez azonban a terheléskor szükséges további vazodilatációs kapacitás korlátozottságával jár, ami megmagyarázza az ilyenkor várhatóan csökkent CFR-t. Hogyan értelmezhetjük a mérések 20-30\%-ban előforduló jelentős eltérést a nyugalmi és hyperaemiás nyomásarányok között?

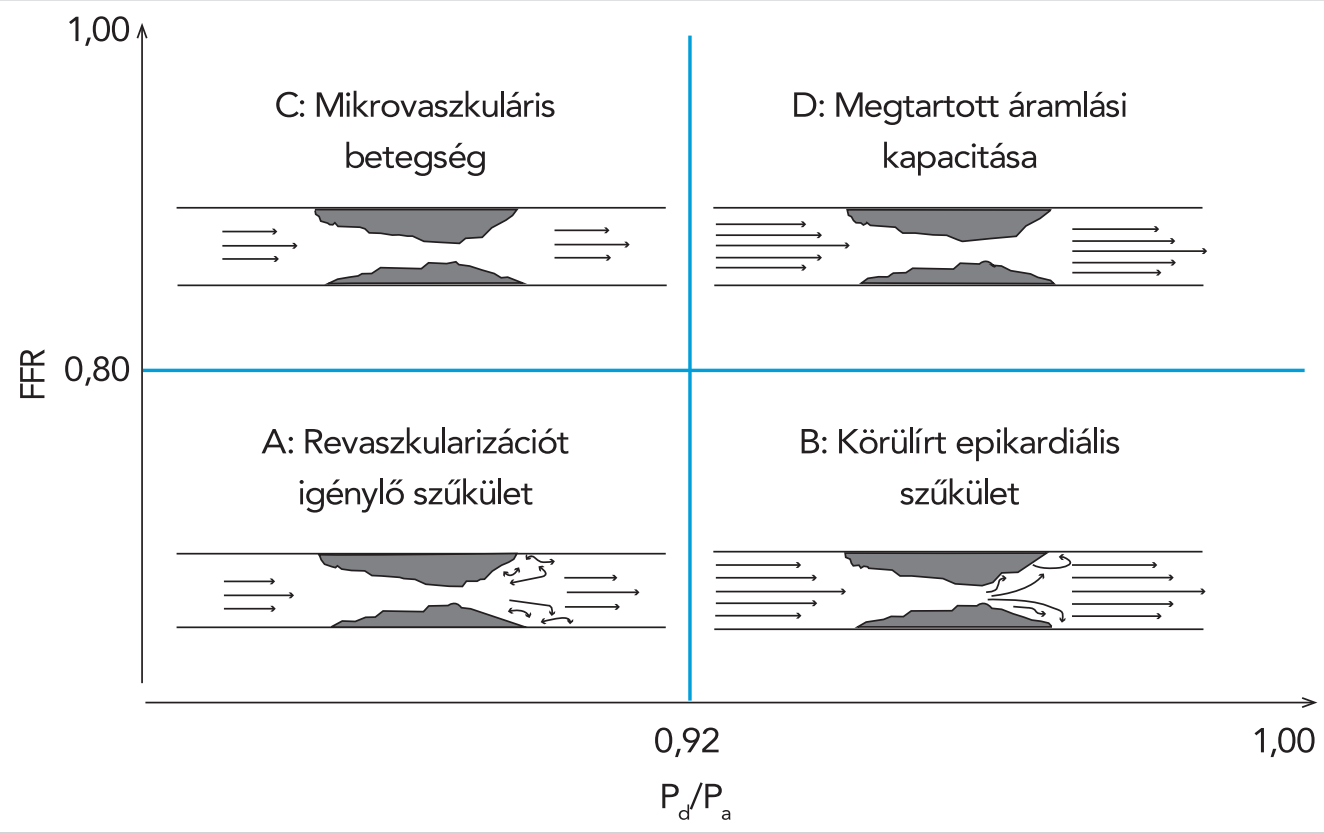

1. ÁBRA. Az intermedier mértékű koszorúér-szűkületeken mérhető nyugalmi és hyperaemiás nyomásarányok által tipizálható hemodinamikai konstellációk ( $A-D$ értípusok). A nyilak a hyperaemiában kialakuló áramlást jelképezik (26). A, D: konkordáns FFR- $P_{\mathrm{d}} / P_{\mathrm{a}}$ értékek egybehangzóan kóros $(A)$ és normál áramlási mintákkal; B: Fokális epikardiális szűkület nem bizonyítható iszkémiával; C: Dominálóan mikrovaszkuláris betegség miatti csökkent áramlás 
Úgy tűnik, hogy az eltérések nem elsősorban módszertani eredetűek, mivel meghatározhatóak azok a patofiziológiai konstellációk, amelyek diszkordáns FFR- $\mathrm{P}_{\mathrm{d}} /$ $\mathrm{P}_{\mathrm{a}}$-értéket eredményeznek (25-27). Említettük már azt az esetet, amikor a nyugalmi nyomásarány normális, de az FFR kóros értéket ad (1. ábra B-típusú ér). Ez megtartott vazoreaktivitás mellett képzelhető el, nem feltétlenül iszkémiát okozó mérsékelt szűkület esetében. Mivel a szűkületet követő áramlásszétválás esetén a volumetrikus áramlás négyzetével arányos a nyomásesés kialakulása, így a jelentős vazodilatációs nyomásgrádiens-fokozódás kóros FFR-értéket adhat abban az esetben is, ha a CFR (és a hyperaemiás áramlás) megtartott.

Ha azonban az FFR normális, de a nyugalmi nyomásarány a meghatározott küszöbérték alatt van, akkor azt feltételezhetjük, hogy a vazodilatációs reakció alacsony, és az alacsony áramlásfokozódás miatt az egyébként jelentős koszorúér-ellenállás ellenére lesz alacsony a nyomásesés, így marad az FFR-érték normál tartományban (1. ábra C-típusú ér) (22-27). A nyugalmi nyomásarány alacsony volta viszont a nyugalmi autoregulációs vazodilatáció jelenlétére utal, ami minden esetben a vazodilatációs kapacitás korlátozottságával jár együtt.

Megjegyzendő, hogy az utóbbi szcenárió esetén stenteléssel sem tudunk megfelelö áramlásnövekedés elérni, hiszen nem a körülírt áramlási akadály, hanem a csökkent mikrovaszkuláris funkció és/vagy a diffúz érbetegség okozza az alacsony nyugalmi nyomásarányt és az ezzel járó beszűkült koszorúérrezervet.

Saját vizsgálatunkban 32 betegnél hasonlítottuk össze az invazív úton mért nyugalmi- és vazodilatációs nyomásarányt (26). Áramlásdinamikai egyenletek alapján a nyomásadatok és a 3D rekonstrukciós paraméterek

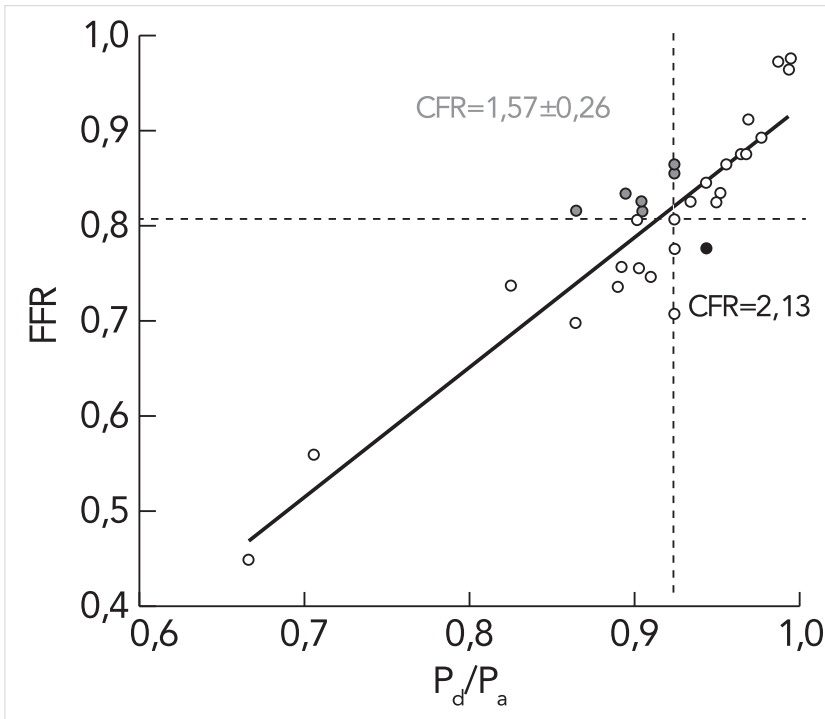

2. ÁBRA. 32 mérés nyugalmi $P_{d} / P_{a}$ és vazodilatációs (FFR) nyomásarány értékei, valamint a 7 diszkordáns eset CFR értékei

segítségével minden esetben kiszámítottuk a CFR-t is (26). Bár a nyugalmi és a hyperaemiás nyomásarányok erősen korreláltak egymással $(r=0,91 ; p<0,0001)$, 32 mérésből 7-nél mégis előfordult diszkordáns FFR$P_{d} / P_{a}$ érték. A számított CFR 2,13-nak adódott abban a diszkordáns esetben, ahol a nyugalmi nyomásarány

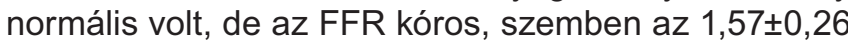
CFR-értékkel azoknál, akiknél normális FFR mellett csökkent $P_{d} / P_{a}$-t mértünk. Az utóbbi 6 eset mindegyikében kóros CFR (<2) értéket számoltunk (2. ábra).

Milyen stratégia tanácsolható az intermedier mértékú koszorúér-szükület megítélésére a szívkatéteres laboratóriumban?
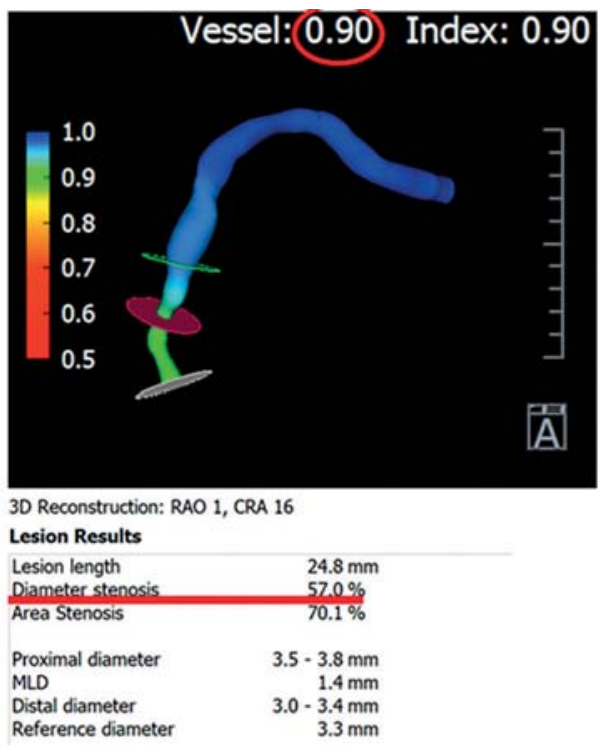

3. ÁBRA. Bal oldalon natív jobb koszorúér QFR számítása nem szignifikáns $(0,90)$ értéket mutat. Jobb oldalon a jobb koszorúérhez menő véna graft QFR-analízise szignifikáns (QFR: 0,72) szűkületet igazol. Az átmérőszűkület mértéke nagyon hasonló a két esetben (57, illetve 56\%), de eltérő funkcionális következménnyel járnak 


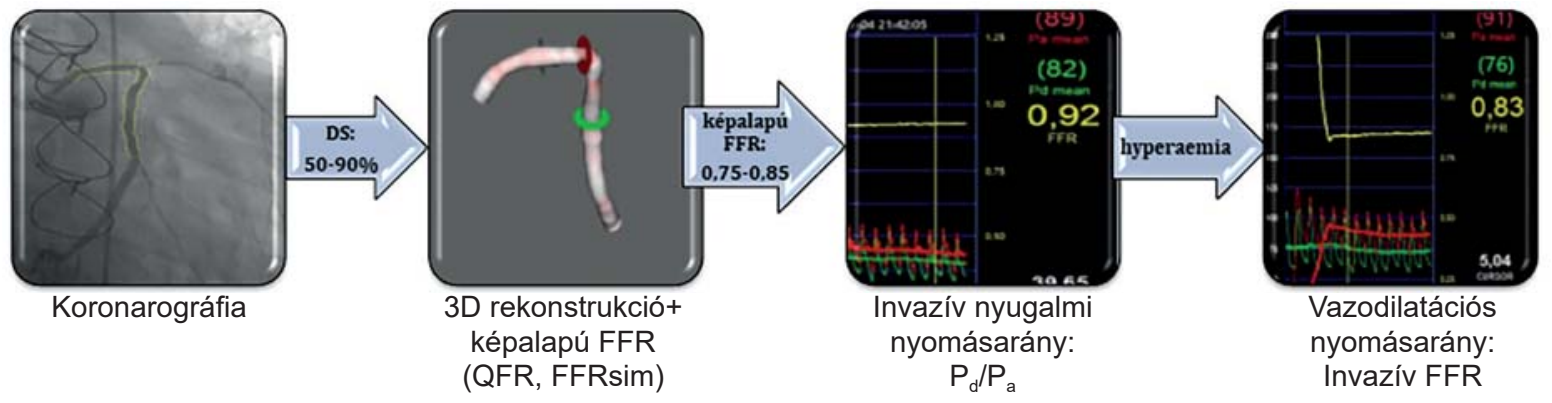

4. ÁBRA. Koronarográfiát követően az intermedier koszorúér-szűkület képalapú (image based) FFR meghatározása végezhető. Ha az így meghatározott érték a döntési határ közelébe esik (0,75 és a 0,85 között), akkor érdemes lehet az invazív nyomásmérő drótot is elővenni. A nyomásmérő drót levezetését követően közvetlenül leolvasható a nyugalmi nyomásarány. Ha vazodilatáció alkalmazása mellett döntünk, úgy megkapjuk az FFR-értéket. A nyugalmi és a vazodilatációs nyomásarány összehasonlításával lehetőségünk nyílik arra, hogy jellemezzük az adott ér patofiziológiáját

Manapság már elérhető, hogy a koszorúérfestésből közvetlenül kiszámítsuk az áramlási akadály okozta nyomásesést, és ezáltal a szükület jelentőségére következtessünk. Mivel ez a legkevésbé invazív és legolcsóbb módszer, így amennyiben további tanulmányok is igazolják a módszer pontosságát, úgy várhatóan első helyen lesz javasolható a képalapú (image based FFR) meghatározás. Az image based FFR-számítás előnye, hogy nyomásmérő drót nélkül, egyszerűen a koronarográfián látott képből, háromdimenziós rekonstrukciót követően az áramlásdinamikai törvények alapján számíthatjuk ki bizonyos pontossággal az éren kialakuló nyomásesést. Az eddigi eredmények szerint ezek a kevésbé invazív módszeren alapuló képalapú FFR-értékek jól közelítik az invazív módszerrel mért FFR-t (28-30).

A legelterjedtebb ilyen eljárás jelenleg a Medis cég által forgalmazott QFR-szoftver (3. ábra). Munkacsoportunk közölt egy egyszerüsített számítási eljárást is, amely egy Excel táblázat használatával a háromdimenziós rekonstruált koronária-paraméterekből áramlásdinamikai egyenleteket használva szintén elfogadható pontossággal adja meg az FFR-értéket. FFR sim -mel jelöltük az értékünket, utalva az egyszerüsített (simple) számításra (29). Megjelent egy metaanalízis arról, hogy a különböző kevésbé invazív FFR-számítások hasonló pontossággal képesek az invazív FFR-t előre jelezni (31), és az egyes vizsgálati eljárásokra meghatározták azt az eredmény-intervallumot, ahol a diagnosztikus döntést az invazív FFR-rel teljes összhangban lehet végezni (28-30).)

Maradt azonban egy átmeneti „szürke” zóna, ahol a képalapú számítás jelentős bizonytalanságot mutat. A 0,75-0,85 tartományban mindenképpen javasolható az invazív nyomásmérő dróttal pontosabban meghatározható nyomásgrádiens mérése. Ha már használjuk az invazív nyomásmérő drótot, továbbra is felmerül a kérdés, hogy használjunk-e hozzá vazodilatátor ágenst is? Tekintve, hogy a nyugalmi nyomásarány minden esetben magasabb, mint a hyperaemia alatti érték, így elmondható, hogy ha a nyugalmi nyomásarány $<0,80$, akkor az FFR biztosan kóros értékű (hiszen a vazodilatáció alatt csak ennél alacsonyabb nyomásarány képzelhető el). Ilyenkor a vazodilatáció diagnosztikus célú alkalmazására nincs szükség. Ha azonban teljes elemzést akarunk az adott ér patofiziológiájáról, úgy hasznos lehet, hogy a nyugalmi nyomásarány mellett a vazodilatációs nyomásarányt is meghatározzuk. A fenti gondolatmentet összefoglaló hibrid stratégia folyamatábráját a 4. ábrán mutatjuk be. Az algoritmus végig vitelével komplex képet kaphatunk az adott ér patofiziológia jellemzőiről, így meghozhatjuk a megfelelő döntést a revaszkularizáció szükségességét és a gyógyszeres kezelés irányát illetően. PI. a mikrovaszkuláris betegségre utaló normál FFR és alacsony $P_{d} / P_{a}$ esetén $a z$ ACE-gátló és a béta-blokkoló kezelést ajánlják elsősorban (32).

A jelenlegi gyakorlat azonban sajnos az, hogy a fiziológiai mérések a krónikus koronária szindrómával katéterezésre kerülő betegeknél nemcsak Magyarországon, de a világon is alig érik el a 10-20 százalékos arányt. A koszorúérbetegek sokkal szélesebb körében érhetnénk el a fiziológiai értékelést, ha image based alapon kezdenénk az FFR meghatározását. Feltételezhető, hogy intermedier szükületek esetén a képalapú meghatározás az esetek körülbelül kétharmad részében egyértelmüen megmutatná a szükület jelentőségét. A maradék egyharmad részben válna szükségessé az invazív nyomásmérő szenzorral történő mérés. Ha ilyen arányú pressure wire mérés történne, az a jelenlegi invazív nyomásmérések számát a fenti megfontolások szerint két-háromszorosára emelné, a komplex fiziológiai értékelés pedig teljeskörűvé válna.

\section{IRODALOM}

1. Gruntzig AR, Senning A, Siegenthaler WE, et al. Nonoperative dilatationof coronary artery stenosis: percutaneous transluminal coronary angioplasty. N Engl J Med 1979; 301: 61-8. DOI: 10.1056/ NEJM197907123010201

2. Peterson RJ, King SB $3^{\text {rd }}$, Fajman WA, et al. Relation of coronary artery stenosis and pressure gradient to exercise-induced ischemia 
before and after coronary angioplasty. J Am Coll Cardiol 1987; 10(2): 253-60. DOI: 10.1016/s0735-1097(87)80004-9

3. De Bruyne B, Baudhuin T, Melin JA, et al. Coronary flow reserve calculated from pressure measurements in humans. Validation with positron emission tomography. Circulation 1994; 89: 1013-1022. DOI: 10.1161/01.cir.89.3.1013

4. Pijls NHJ, De Bruyne B, Peels K, et al. Measurement of fractional flow reserve to assess the functional severity of coronary-artery stenoses. N Engl J Med 1996; 334: 1703-1708. DOI: 10.1056/ NEJM199606273342604

5. Pijls NHJ, van Schaardenburgh P, Manoharan G, et al. Percutaneous Coronary Intervention of Functionally Nonsignificant Stenosis. 5-Year Follow-Up of the DEFER Study. J Am Coll Cardiol 2007; 49: 2105-2111. DOI: 10.1016/j.jacc.2007.01.087

6. Tonino PAL, De Bruyne B, Pijls NHJ, et al. Fractional flow reserve versus angiography for guiding percutaneous coronary intervention. N Engl J Med 2009; 360: 213-224. DOI: 10.1056/NEJMoa0807611

7. Pijls NHJ, Fearon WF, Tonino PA, et al. Fractional flow reserve versus angiography for guiding percutaneous coronary intervention in patients with multivessel coronary artery disease: 2-year follow-up of the FAME (Fractional Flow Reserve Versus Angiography for Multivessel Evaluation) study. J Am Coll Cardiol 2010; 56: 177184. DOI: $10.1016 /$ j.jacc.2010.04.012

8. De Bruyne B, Pijls NH, Kalesan B, et al. Fractional flow reserve-guided $\mathrm{PCl}$ versus medical therapy in stable coronary disease. $\mathrm{N}$ Engl J Med 2012; 367(11): 991-1001. DOI: 10.1056/NEJMoa1205361 9. Fearon WF, Nishi T, De Bruyne B, et al. Clinical Outcomes and Cost-Effectiveness of Fractional Flow Reserve-Guided Percutaneous Coronary Intervention in Patients With Stable Coronary Artery Disease: Three-Year Follow-Up of the FAME 2 Trial (Fractional Flow Reserve Versus Angiography for Multivessel Evaluation). Circulation 2018; 137(5): 480-487. DOI: 10.1161/CIRCULATIONAHA.117.031907

10. Wijns W, Kohl P, Danchin N, et al. Guidelines on myocardial revascularization. The Task Force on Myocardial Revascularization of the European Society of Cardiology (ESC) and the European Association for Cardio-Thoracic Surgery (EACTS). Eur Heart J 2010; 31 2501-2555. DOI: 10.1016/j.ejcts.2010.08.019

11. B Tar, S Bakk, Z Beres, et al. The laminar resistance of the coronary segment between the lesion and the sensor of the pressure wire significantly influences the fractional flow reserve. Eur Heart $J$ 2014; 9(1): 812 (abstract)

12. Härle T, Luz M, Meyer S, Kronberg K, Nickau B, Escaned J, Davies J, Elsässer A. Effect of coronary anatomy and hydrostatic pressure on intracoronary indices of stenosis severity. JACC Cardiovasc Interv 2017; 10: 764-773. DOI: 10.1016/j.jcin.2016.12.024

13. De Bruyne B, Bartunek J, Sys SU, et al. Relation between myocardial fractional flow reserve calculated from coronary pressure measurements and exercise-induced myocardial ischemia. Circulation 1995; 92: 39-46. DOI: 10.1161/01.cir.92.1.39

14. Davies JE, Sen S, Dehbi HM, et al. Use of the instantaneous wave-free ratio or fractional flow reserve in PCI. N Engl J Med 2017; 376: 1824-1834. DOI: 10.1056/NEJMoa1700445

15. Götberg M, Christiansen EH, Gudmundsdottir IJ, et al. Instantaneous wave-free ratio versus fractional flow reserve to guide $\mathrm{PCl}$ N Engl J Med 2017; 376: 1813-1823. DOI: 10.1056/NEJMoa1616540 16. Knuuti J, Wijns W, Saraste A, et al. 2019 ESC Guidelines for the diagnosis and management of chronic coronary syndromes. The Task Force for the diagnosis and management of chronic coronary syndromes of the European Society of Cardiology (ESC) Eur Heart J 2019; 00: 1-71. DOI: 10.1093/eurheartj/ehz425

17. Hennigan B, Oldroyd KG, Berry C, et al. Discordance Between Resting and Hyperemic Indices of Coronary Stenosis Severity: The VERIFY 2 Study (A Comparative Study of Resting Coronary Pressure Gradient, Instantaneous Wave-Free Ratio and Fractional Flow
Reserve in an Unselected Population Referred for Invasive Angiography). Circ Cardiovasc Interv 2016; 9(11). DOI: 10.1161/CIRCINTERVENTIONS.116.004016

18. Berry C, McClure JD, Oldroyd KG Meta-Analysis of Death and Myocardial Infarction in the DEFINE-FLAIR and iFR-SWEDEHEART Trials. Circulation 2017; 136: 2389-91. DOI: 10.1161/CIRCULATIONAHA.117.030430

19. Sen S, Ahmad Y, Dehbi HM, et al. Clinical Events After Deferral of LAD Revascularization Following Physiological Coronary Assessment. J Am Coll Cardiol 2019; 73(4): 444-453. DOI: 10.1016/j. jacc.2018.10.070

20. Gan LM, Wikström J, Fritsche-Danielson R. Coronary flow reserve from mouse to man--from mechanistic understanding to future interventions. J Cardiovasc TransI Res 2013; 6(5): 715-28. DOI: 10.1007/s12265-013-9497-5

21. Cortigiani L, Rigo F, Gherardi, et al. Coronary flow reserve during dipyridamole stress echocardiography predicts mortality JACC Cardiovasc Imaging 2012; 5(11): 1079-1085. DOI: 10.1016/j. jcmg.2012.08.007.

22. Murthy VL, Naya M, Foster, et al. Improved cardiac risk assessment with noninvasive measures of coronary flow reserve. Circulation 2011; 124(20): 2215-2224. DOI: 10.1161/CIRCULATIONAHA.111.050427.

23. Gould KL, Johnson NP, Bateman TM, et al. Anatomic versus physiologic assessment of coronary artery disease: role of coronary flow reserve, fractional flow reserve, and positron emission tomography imaging in revascularization decision making. J Am Coll Cardiol 2013; 62: 1639-53. DOI: 10.1016/j.jacc.2013.07.076

24. van de Hoef TP, van Lavieren MA, Damman $P$, et al. Physiological basis and long-term clinical outcome of discordance between fractional flow reserve and coronary flow velocity reserve in coronary stenoses of intermediate severity. Circ Cardiovasc Interv 2014 7: 301-311. DOI: 10.1161/CIRCINTERVENTIONS.113.001049

25. Johnson NP, Kirkeeide RL, Gould KL. Is discordance of coronary flow reserve and fractional flow reserve due to methodology or clinically relevant coronary pathophysiology? JACC Cardiovasc Imaging 2012; 5(2): 193-202. DOI: 10.1016/j.jcmg.2011.09.020

26. Uveges A, Balogh F, Tar B, et al. Discordant resting and hyperemic pressure gradients in relation to the coronary flow reserve Eu Heart J 2018; 39(suppl 1): P5507 (abstract)

27. Echavarría-Pinto $M$, van de Hoef TP, van Lavieren MA, et al. Combining Baseline Distal-to-Aortic Pressure Ratio and Fractional Flow Reserve in the Assessment of Coronary Stenosis Severity. JACC Cardiovasc Interv 2015; 8(13): 1681-91. DOI: 10.1016/j. jcin.2015.09.002

28. Westra J, Andersen BK, Campo G, et al. Diagnostic Performance of In-Procedure Angiography-Derived Quantitative Flow Reserve Compared to Pressure-Derived Fractional Flow Reserve: The FAVOR II Europe-Japan Study. J Am Heart Assoc 2018; 7(14) e009603. DOI: 10.1161/JAHA.118.009603

29. Tar B, Jenei C, Dezsi CA, et al. Less invasive fractional flow reserve measurement from 3-dimensional quantitative coronary angiography and classic fluid dynamic equations. Eurolntervention 2018; 14(8): 942-950. DOI: 10.4244/EIJ-D-17-00859

30. Kornowski R, Lavi I, Pellicano M, et al. Fractional flow reserve derived from routine coronary angiograms. J Am Coll Cardiol 2016; 68: 2235-2237. DOI: 10.1016/j.jacc.2016.08.051

31. Collet C, Onuma Y, Sonck J, et al. Diagnostic performance of angiography-derived fractional flow reserve: a systematic review and Bayesian meta-analysis. Eur Heart J 2018; 39(35): 3314-3321. DOI: 10.1093/eurheartj/ehy445.

32. Ford TJ, Berry C. How to Diagnose and Manage Angina Without Obstructive Coronary Artery Disease: Lessons from the British Heart Foundation CorMicA Trial. Interv Cardiol 2019; 14(2): 76-82. DOI: 10.15420/icr.2019.04.R1 